\title{
PERBANDINGAN METODE APLIKASI JAMUR ENTOMOPATOGEN BEAUVERIA BASSIANA UNTUK PENGENDALIAN CYLAS FORMICARIUS (COLEOPTERA: CURCULIONIDAE)
}

\author{
Yusmani Prayogo \\ Balai Penelitian Tanaman Aneka Kacang dan Umbi \\ Jl. Raya Kendalpayak, KM 08, PO BOX 66 Malang, 65101 \\ E-mail: yusmani.prayogo@yahoo.com
}

\begin{abstract}
Comparing application methods of entomopathogenic fungus Beauveria bassiana to control Cylas formicarius (Coleoptera: Curculionidae). Cylas formicarius is a major pest of sweet potatoes. The tuber damage caused by $C$. formicarius reaches $100 \%$. The research objective was to compare application methods of entomopathogenic fungi Beauveria bassiana to control C. formicarius. The research was conducted at the entomology screen house of Indonesian Legume and Tuber Crops Research Institute (ILETRI) at Malang, East Java, from January to September 2013. The treatment consisted of 12 application methods, each was repeated three times. The results showed that application of $B$. bassiana into the planting pit, soaking the sweet potato cuttings into the conidial suspension of $B$. bassiana for 30 minutes before planting, followed by spray application with two week interval (2 to 12 weeks after planting, WAP) or P4 was effective in suppressing $C$. formicarius population and tuber damage. Tuber weight obtained from P4 treatment was $1.4 \mathrm{~kg} \mathrm{plant}^{-1}$, while from the chemical insecticide was only 1.1 $\mathrm{kg} \mathrm{plant}^{-1}$. Tuber damage from P4 treatment was lower ( $\left.5 \%\right)$ than that from chemical insecticide treatment (42\%). Therefore, application of B. bassiana conidial suspension in the planting pit, continued by soaking the sweet potato cuttinginto the B. bassiana conidial suspension for 30 minutes before planting, and followed by spray applications of B. bassiana conidial suspension at two-week intervals (2-12 WAP) or P4 method can be recommended to control C. formicarius.
\end{abstract}

Key words: adult, egg, larvae, tuber damage, tuber weight

\begin{abstract}
ABSTRAK
Perbandingan metode aplikasi jamur entomopatogen Beauveria bassiana untuk pengendalian Cylas formicarius (Coleoptera:Ccurculionidae). Cylas formicarius merupakan hama utama ubi jalar. Kerusakan yang disebabkan $C$. formicarius mencapai $100 \%$. Penelitian ini bertujuan untuk membandingkan metode aplikasi jamur entomopatogen, Beauveria bassiana dalam mengendalikan C. formicarius. Penelitian dilakukan di rumah kasa entomologi, Balai Penelitian Tanaman Aneka Kacang dan Umbi (BALITKABI), Malang pada bulan Januari sampai dengan September 2013. Perlakuan terdiri atas 12 metode aplikasi, masing-masing perlakuan diulang tiga kali. Hasil penelitian menunjukkan bahwa aplikasi konidia B. bassiana ke dalam lubang tanam, perendaman stek ke dalam suspensi konidia jamur B. bassiana selama 30 menit sebelum tanam, dilanjutkan aplikasi semprot dengan interval dua minggu mulai umur 2 sampai dengan 12 minggu setelah tanam (MST) (P4) efektif menekan populasi $C$. formicarius dan kerusakan umbi. Berat umbi perlakuan P4 mencapai 1,4 kg tanaman ${ }^{-1}$, sedangkan perlakuan aplikasi insektisida kimia hanya $1,1 \mathrm{~kg} \operatorname{tanaman}^{-1}$. Kerusakan umbi perlakuan P4 hanya 5\%, sedangkan kerusakan umbi pada aplikasi insektisida kimia mencapai 42\%. Efikasi perlakuan P4 dapat dilihat dari populasi telur, larva maupun imago pada waktu panen lebih sedikit dibandingkan dengan perlakuan lainnya. Oleh karena itu, aplikasi suspensi konidia B. bassiana pada lubang tanam, perendaman stek selama 30 menit dan aplikasi tiap dua minggu pada umur 2 sampai dengan 12 MST (P4) dapat dianjurkan sebagai teknologi untuk pengendalian $C$. formicarius.
\end{abstract}

Kata kunci: bobot umbi, imago, kerusakan umbi, larva, telur

\section{PENDAHULUAN}

Usaha peningkatan produksi ubi jalar di Indonesia masih mengalami kendala berbagai masalah antara lain; lemahnya penggunaan varietas unggul, sistem budidaya maupun adanya serangan hama dan penyakit (Suwarto et al., 2006; Jusuf 2007; Djufry et al., 2011; Mau et al., 2011; Saleh \& Rahayuningsih, 2013). Salah satu hama utama ubi jalar adalah penggerek umbi yang disebabkan oleh Cylas formicarius (Jackai et al., 2006; Reddy et al., 2012b). Kerugian hasil yang disebabkan oleh hama ini mencapai $100 \%$. Umbi yang sudah tergerek larva 
C. formicarius tidak layak dikonsumsi manusia karena mengandung racun yang dapat mengakibatkan penyakit kanker. Pengendalian $C$. formicarius menggunakan insektisida kimia belum menunjukkan hasil yang memuaskan (Smith \& Hammond, 2006; Leng et al., 2012; Reddy et al., 2012a). Hal ini disebabkan senyawa insektisida kimia yang diaplikasikan ke permukaan tanaman tidak mampu menjangkau larva yang berada di dalam umbi. Berbagai upaya untuk menanggulangi C. formicarius terus dikembangkan (Tarafdar \& Sarkar 2006; Foglie, 2007; Korada et al., 2010; Reddy et al., 2014; Hue \& Low, 2015), salah satunya adalah upaya pengendalian hayati menggunakan jamur entomopatogen (Gindin et al., 2006; Ondiaka et al., 2008; Shams et al., 2011; Khosravi et al., 2015).

Beauveria bassiana merupakan salah satu jamur entomopatogen yang memiliki kelebihan dalam menginfeksi banyak ordo dari berbagai fase kehidupan serangga, sehingga cukup prospektif digunakan sebagai alternatif insektisida kimia (Meyling \& Eilenberg, 2007; Ondiaka et al., 2008; Reddy et al., 2014). Hasil penelitian tahun 2010 menunjukkan bahwa jamur B. bassiana efektif membunuh imago, larva, maupun menggagalkan penetasan telur $C$. formicarius mencapai 100\% (Prayogo, 2012 \& 2013). Isolat jamur B. bassiana yang diperoleh dari Bogor, Probolinggo, dan Tumpang (Malang) memiliki patogenisitas lebih tinggi terhadap larva maupun imago $C$. formicarius dibandingkan dengan isolat yang diperoleh dari lokasi lain (Prayogo, 2012). Hal ini mengindikasikan bahwa perbedaan asal isolat memiliki keragaman patogenisitas yang berbeda (Mwamburi et al., 2010; Sharififar et al., 2011; Mishra \& Malik, 2012; Qazzaz et al., 2015).

Pengendalian hama penggerek ubi jalar menggunakan jamur entomopatogen $B$. bassiana mempunyai prospek yang baik dan dapat dikembangkan karena aman terhadap serangga berguna serta tidak mencemari lingkungan (Zimmermann, 2007; Meikle et al., 2008; Haas-Costa et al., 2010; Li et al., 2011). Hasil penelitian Shi et al. (2008); Stafford \& Allan (2010) aplikasi jamur B. bassiana pada permukaan daun cukup efektif mengendalikan hama tungau. Aplikasi suspensi jamur $B$. bassiana di lahan terbuka pada kondisi kering juga mampu membunuh serangga dari kelompok aphid (Bugeme et al., 2009). Aplikasi jamur B. bassiana di permukaan tanah lebih efektif, namun efikasi jamur tersebut lebih dipengaruhi oleh jenis dan perilaku hama yang dikendalikan (Stanghellini \& ElHamalawi, 2005; Ali et al., 2009). Penelitian ini bertujuan untuk membandingkan metode aplikasi jamur entomopatogen $B$. bassiana untuk mengendalikan hama penggerek ubi jalar (C. formicarius).

\section{METODE PENELITIAN}

Tempat dan Waktu. Penelitian dilakukan di kebun percobaan (KP) Kendalpayak dan Laboratorium Entomologi, Balai Penelitian Tanaman Aneka Kacang dan Umbi (BALITKABI), Malang dari bulan Januari sampai dengan bulan September 2013.

Susunan Perlakuan. Perlakuan disusun dalam rancangan acak kelompok (RAK) dan diulang tiga kali. Perlakuan adalah berbagai metode aplikasi suspensi konidia jamur entomopatogen $B$. bassiana antara lain; pada pangkal stek ubi jalar yang ditanam dengan cara direndam selama 30 menit, aplikasi di lubang tanam maupun aplikasi dengan cara penyemprotan pada pangkal batang tanaman secara simultan mulai umur 212 minggu setelah tanam (MST) dengan interval dua minggu (Tabel 1).

Penyiapan Serangga Uji. Imago $C$. formicarius dipelihara di dalam kotak plastik yang berisi umbi ubi jalar segar sebagai pakan. Kotak plastik ditutup kain kasa agar serangga yang akan dipelihara tidak keluar dari kotak pemeliharaan. Perkembangbiakan serangga dilakukan terus menerus hingga memperoleh populasi imago sebanyak 2000 ekor untuk perlakuan. Serangga yang diinfestasikan ke tanaman adalah imago hasil pemeliharaan di laboratorium pada generasi F2.

Penyiapan Tanaman. Stek ubi jalar varietas Sari yang digunakan ditanam di dalam polybag yang berisi tanah $10 \mathrm{~kg}$. Tiap polybag ditanami satu batang stek ubi jalar yang digunakan sebagai unit perlakuan. Tanaman dipupuk menggunakan dosis setara $100 \mathrm{~kg}$ Urea, $100 \mathrm{~kg} \mathrm{SP36}$, dan $100 \mathrm{~kg} \mathrm{KCl} \mathrm{ha}{ }^{-1}$. Gulma disiangi dan pengairan diberikan sesuai dengan kebutuhan. Tanaman pada umur 2 bulan disungkup menggunakan kain kasa halus yang tembus sinar matahari selanjutnya dilakukan infestasi imago $C$. formicarius sebanyak 10 pasang jantan dan betina tiap tanaman.

Penyiapan Jamur B. bassiana. Jamur B. bassiana yang digunakan adalah isolat $\mathrm{Pb}-\mathrm{Bb}$ yang diperoleh dari eksplorasi di pertanaman ubi jalar di Probolinggo, hasil uji efikasi memiliki virulensi tinggi terhadap $C$. formicarius. Selanjutnya, isolat jamur $\mathrm{Pb}-\mathrm{Bb}$ dikulturkan pada media potato dextrose agar (PDA) di dalam cawan petri. Biakan jamur yang berumur 21 hari setelah inokulasi (HSI), diambil konidianya dengan cara dikerok menggunakan kuas halus pada 
permukaan koloni jamur. Konidia jamur dicampur dengan air kemudian ditambahi Tween 20 sebanyak $2 \mathrm{ml} \mathrm{L}^{-1}$ selanjutnya dikocok menggunakan shaker (099A WS 18012) selama 30 detik sampai konidia tercampur secara homogen. Suspensi konidia dihitung menggunakan haemocytometer (Neubauer No. 1280 NESCO) untuk mendapatkan kerapatan konidia $10^{8}$ $\mathrm{ml}^{-1}$ sebelum diaplikasikan pada masing-masing perlakuan. Aplikasi suspensi konidia jamur $B$. bassiana dilakukan dengan berbagai cara; (1) menuangkan suspensi konidia ke tiap lubang tanam sebanyak $100 \mathrm{ml}$, (2) merendam pangkal stek ubijalar yang akan ditanam selama 30 menit, dan (3) menyemprotkan suspensi konidia $B$. bassiana ke pangkal batang tanaman pada umur 2, 4, 6, 8, 10, dan 12 MST. Insektisida kimia yang berbahan aktif deltametrin dengan dosis $2 \mathrm{ml} \mathrm{L}^{-1}$ volume semprot $600 \mathrm{~L}^{-1}$ yang diaplikasikan tiap dua minggu, pada umur 2-12 MST. Perlakuan kontrol hanya disemprot menggunakan air steril (tanpa aplikasi jamur $B$. bassiana maupun insektisida kimia).

Peubah yang diamati adalah (1) jumlah umbi tiap tanaman, (2) bobot umbi tiap tanaman, (3) persentase kerusakan umbi, (4) jumlah telur $C$. formicarius, (5) jumlah larva $C$. formicarius, dan (6) jumlah imago $C$. formicarius yang terbentuk. Kerusakan umbi akibat serangan $C$. formicarius dinilai berdasarkan skor kerusakan yang terbagi ke dalam lima tingkat (Zuraida et al., 2005) yaitu: $0=\quad$ Tanpa ada gejala gerekan pada umbi $(0 \%)$

$1=$ Kerusakan umbi oleh C. formicarius antara 1$25 \%$

$2=$ Kerusakan umbi oleh - C. formicarius antara $26-50 \%$

$3=$ Kerusakan umbi oleh C. formicarius antara 51$75 \%$

$4=$ Kerusakan umbi oleh C. formicarius $\geq 76 \%$ (umbi tidak layak dikonsumsi)

Analisis Data. Semua data yang diperoleh dianalisis menggunakan program MINITAB versi 14. Setelah itu, apabila terdapat perbedaan di antara perlakuan maka dilanjutkan uji jarak berganda (Duncan's Multiple Range Test) pada taraf nyata $\alpha=0,05$.

\section{HASIL DAN PEMBAHASAN}

Bobot Umbi. Keragaan pertumbuhan tanaman antar perlakuan secara visual tidak tampak berbeda terutama apabila ditinjau dari pertumbuhan daun, karena tidak ada daun yang mengalami kerusakan akibat serangan $C$. formicarius mulai awal pertumbuhan sampai dengan panen. Namun perlakuan aplikasi suspensi konidia jamur $B$. bassiana berpengaruh nyata terhadap bobot umbi yang dihasilkan tiap tanaman. Bobot umbi tertinggi diperoleh pada perlakuan P4 yaitu mencapai $1406 \mathrm{~g}$ $\operatorname{tanaman}^{-1}$ (Gambar 1). Kondisi ini dapat terjadi karena

Tabel 1. Metode aplikasi suspensi konidia cendawan B. bassiana untuk pengendalian hama penggerek ubijalar C. formicarius

\begin{tabular}{|c|c|c|c|c|c|c|c|c|c|}
\hline \multirow{3}{*}{ Kode } & \multirow{3}{*}{ Metode aplikasi konidia $B$. bassiana } & \multicolumn{8}{|c|}{ Teknik aplikasi suspensi konidia $B$. bassiana } \\
\hline & & \multirow{2}{*}{ Lubang } & \multirow{2}{*}{ Stek } & \multicolumn{6}{|c|}{$\begin{array}{c}\text { Aplikasi semprot pada } \\
\text { tanaman (MST) }\end{array}$} \\
\hline & & & & 2 & 4 & 6 & 8 & 10 & 12 \\
\hline P1 & Aplikasi di lubang tanam & + & - & - & - & - & - & - & - \\
\hline $\mathrm{P} 2$ & Stek direndam 30 menit sebelum tanam & - & + & - & - & - & - & - & - \\
\hline P3 & $\mathrm{P} 1+\mathrm{P} 2$ & + & + & - & - & - & - & - & - \\
\hline P4 & $\mathrm{P} 1+\mathrm{P} 2+$ aplik. umur $2,4,6,8,10,12 \mathrm{MST}$ & + & + & + & + & + & + & + & + \\
\hline P5 & $\mathrm{P} 2+$ aplik. umur 2, 4, 6, 8, 10, $12 \mathrm{MST}$ & - & + & + & + & + & + & + & + \\
\hline P6 & $\mathrm{P} 1+\mathrm{P} 2+$ aplik. umur $4,6,8,10,12 \mathrm{MST}$ & + & + & - & + & + & + & + & + \\
\hline P7 & $\mathrm{P} 1+\mathrm{P} 2+$ aplik. umur 4,8, dan $12 \mathrm{MST}$ & + & + & - & + & - & + & - & + \\
\hline P8 & $\mathrm{P} 1+\mathrm{P} 2+$ aplik. umur 4, dan $8 \mathrm{MST}$ & + & + & - & + & - & + & - & - \\
\hline P9 & $\mathrm{P} 1+\mathrm{P} 2+$ aplik. umur 4 MST & + & + & - & + & - & - & - & - \\
\hline $\mathrm{P} 10$ & $\mathrm{P} 1+\mathrm{P} 2+$ aplik. umur $8 \mathrm{MST}$ & + & + & - & - & - & + & - & - \\
\hline $\mathrm{P} 11$ & Insektisida kimia (stek, 2, 4, 6, 8, 10, 12 MST) & & & & & & & & \\
\hline $\mathrm{P} 12$ & Tanpa aplikasi (kontrol) & & & & & & & & \\
\hline
\end{tabular}

MST= minggu setelah tanam; (+) aplikasi suspensi konidia B. bassianai; (-) tanpa aplikasi. 
stek yang ditanam sudah diberi perlakuan perendaman suspensi konidia jamur $B$. bassiana, kemudian lubang tanam yang ditanami stek juga sudah diinokulasi menggunakan suspensi konidia sehingga inokulum jamur B. bassiana sudah hidup dan berkembang untuk mengkolonisasi lahan. Selanjutnya dengan adanya perlakuan tambahan aplikasi suspensi konidia pada pertanaman mulai umur $2,4,6,8,10$, dan 12 MST semakin meningkatkan efikasi pengendalian yang diterapkan dalam membunuh $C$. formicarius baik pada fase telur, larva maupun imago. Keadaan ini dapat dibuktikan dari jumlah telur, larva maupun imago penggerek umbi yang teramati pada $\mathrm{P} 4$ berturut-turut satu butir telur, dua ekor larva dan tidak ditemukan imago. Sementara itu, pada perlakuan kontrol (P12) ditemukan stadia telur lima butir, stadia larva sebanyak 40 ekor, dan stadia imago tujuh ekor (Gambar 4). Semakin banyak jumlah larva yang ditemukan pada tiap umbi akan semakin besar pula tingkat kerusakan yang terjadi sehingga berat umbi sehat yang dapat diselamatkan semakin rendah.

Bobot umbi yang diperoleh pada perlakuan P4 tidak berbeda nyata dengan bobot umbi pada perlakuan P5 dan P6, yaitu masing-masing $1341 \mathrm{~g}_{\text {tanaman }}{ }^{-1}$ dan $1339 \mathrm{~g} \mathrm{tanaman}^{-1}$ (Gambar 1). Bobot umbi terendah terjadi pada perlakuan tanpa pengendalian (P12) yaitu $1133 \mathrm{~g}$ tanaman $^{-1}$, bobot umbi tersebut tidak berbeda nyata dengan perlakuan aplikasi insektisida kimia (P11). Hasil penelitian ini mengindikasikan bahwa pengendalian $C$. formicarius menggunakan jamur entomopatogen $B$. bassiana lebih efektif jika dibandingkan dengan insektisida kimia. Namun keberhasilan penggunaan jamur $B$. bassiana untuk mengendalikan $C$. formicarius dipengaruhi oleh cara dan frekuensi aplikasi yang diterapkan. Kenyataan ini didukung oleh penelitian Riyanti et al. (2013) bahwa semakin intensif aplikasi suspensi konidia jamur $B$. bassiana yang diaplikasikan ke tanaman ubi jalar maka akan semakin rendah jumlah umbi yang rusak akibat tergerek $C$. formicarius.

Pengendalian hama penggerek umbi $C$. formicarius menggunakan jamur $B$. bassiana yang diaplikasikan ke lubang tanam satu minggu sebelum tanam, dilanjutkan dengan perendaman pangkal stek ubi jalar ke dalam suspensi konidia $B$. bassiana sebelum tanam selama 30 menit dan ditambah aplikasi dengan cara semprot tiap dua minggu pada pangkal batang tanaman pada umur 2-12 MST (P4, Gambar 1) lebih baik dalam melindungi tanaman dari serangan penggerek dibandingkan dengan perlakuan-perlakuan lain. Kondisi ini disebabkan konidia $B$. bassiana yang diaplikasikan

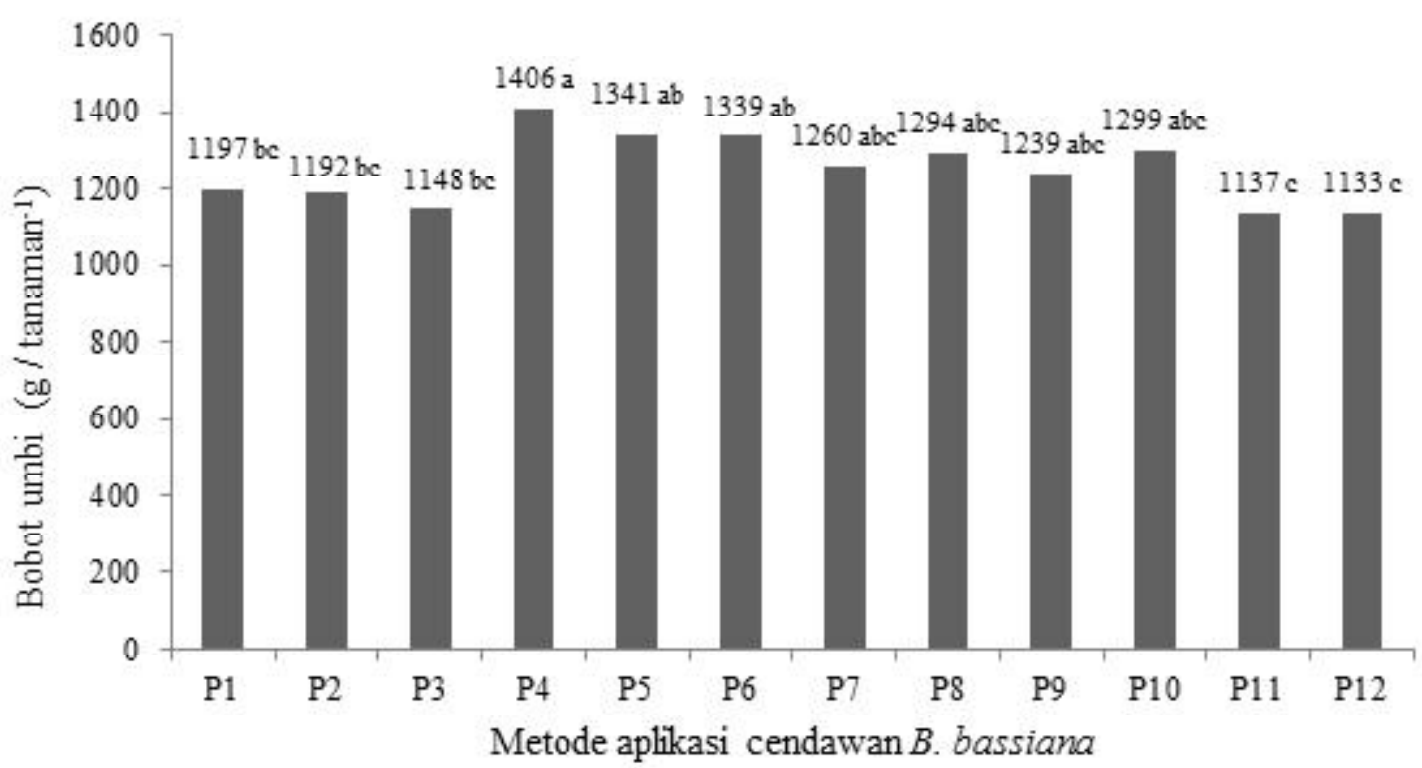

Gambar 1. Bobot umbi tiap tanaman ubi jalar yang diaplikasi menggunakan suspensi cendawan $B$. bassiana dengan berbagai cara dan frekuensi aplikasi. ( $\mathrm{P} 1=$ aplikasi $B$. bassiana di lubang tanam; $\mathrm{P} 2=$ stek direndam 30 menit sebelum tanam; $\mathrm{P} 3=\mathrm{P} 1+\mathrm{P} 2 ; \mathrm{P} 4=\mathrm{P} 1+\mathrm{P} 2+$ aplikasi umur 2, 4, 6, 8, 10, 12 MST; $\mathrm{P} 5=\mathrm{P} 2+$ aplikasi umur 2, 4, 6, 8, 10, $12 \mathrm{MST} ; \mathrm{P} 6=\mathrm{P} 1+\mathrm{P} 2+$ aplikasi umur 4, 6, 8, 10, $12 \mathrm{MST}$; $7=$ $\mathrm{P} 1+\mathrm{P} 2+$ aplikasi umur 4, 8, $12 \mathrm{MST} ; \mathrm{P} 8=\mathrm{P} 1+\mathrm{P} 2+$ aplikasi umur 4, $8 \mathrm{MST} ; \mathrm{P} 9=\mathrm{P} 1+\mathrm{P} 2+$ aplikasi umur 4 MST; P10 = P1 + P2 + aplikasi umur 8 MST; P11 + aplikasi insektisida kimia umur 2, 4, 6, 8, 10, 12 MST; dan P12 kontrol (tanpa pengendalian) 
secara simultan pada perlakuan P4 mempunyai peluang yang besar untuk berkembang karena populasi konidia di lapangan sudah padat sehingga lebih mapan (established) dalam mengolonisasi telur, larva maupun imago C. formicarius. Toksisitas jamur B. bassiana terhadap seluruh fase $C$. formicarius mencapai $100 \%$, terutama terhadap telur sudah dilaporkan Prayogo (2012) dan Artanti et al. (2013). Aplikasi insektisida kimia tidak mampu membunuh seluruh individu $C$. formicarius sehingga imago yang masih hidup mampu berkembang dan meletakkan telurnya ke pangkal umbi. Telur yang sudah diletakkan oleh imago betina selama kurang lebih empat hari kemudian menetas menjadi larva instar I, selanjutnya larva merusak umbi dan akhirnya umbi tidak dapat berkembang sempurna.

Bobot umbi pada perlakuan aplikasi insektisida kimia hanya $1137 \mathrm{~g} \mathrm{tanaman}^{-1}$ dan tidak berbeda nyata dengan kontrol (tanpa pengendalian), yaitu $1133 \mathrm{~g}$ $\operatorname{tanaman}^{-1}$. Perlakuan tersebut hanya mampu membunuh imago $C$. formicarius apabila senyawa yang diaplikasikan mengenai hama sasaran. Hal ini disebabkan imago $C$. formicarius memiliki pergerakan yang sangat cepat dengan cara menerbangkan diri jika terjadi gangguan. Aplikasi insektisida kimia dengan cara semprot secara langsung akan mengganggu imago selanjutnya imago terbang atau pindah ke tempat lain yang dianggap aman. Dengan demikian peluang keberhasilan aplikasi insektisida kimia untuk mengenai hama sasaran terutama imago sangat rendah. Selain itu, insektisida kimia yang diaplikasikan juga tidak mampu menjangkau larva $C$. formicarius yang berada di dalam umbi. Selanjutnya, insektisida kimia juga belum ada yang dinyatakan toksik (ovicidal) untuk membunuh telur serangga (Hoffmann et al., 2008; Suman et al., 2010; Seidenglanz et al., 2011).

Telur dan larva $C$. formicarius yang tidak terbunuh akibat aplikasi insektisida kimia (P11) berkembang secara normal. Kondisi ini disebabkan insektisida tidak bersifat ovisidal dan insektisida yang diaplikasikan hanya ke bagian permukaan tanaman sedangkan larva berkembang di dalam umbi. Larva instar I yang bertahan hidup juga mempunyai kemampuan untuk merusak umbi seperti larva-larva yang lebih besar (instar II, III, IV dan V). Larva instar I yang baru terbentuk langsung menggerek kulit umbi dan masuk ke dalam umbi karena umbi sebagai sumber pakan pada fase larva untuk berkembang menyelesaikan siklus hidupnya sebelum menjadi pupa (Kuriwada et al. 2009; Reddy \& Chi, 2015). Oleh karena itu, pengendalian penggerek umbi $C$. formicarius menggunakan jamur

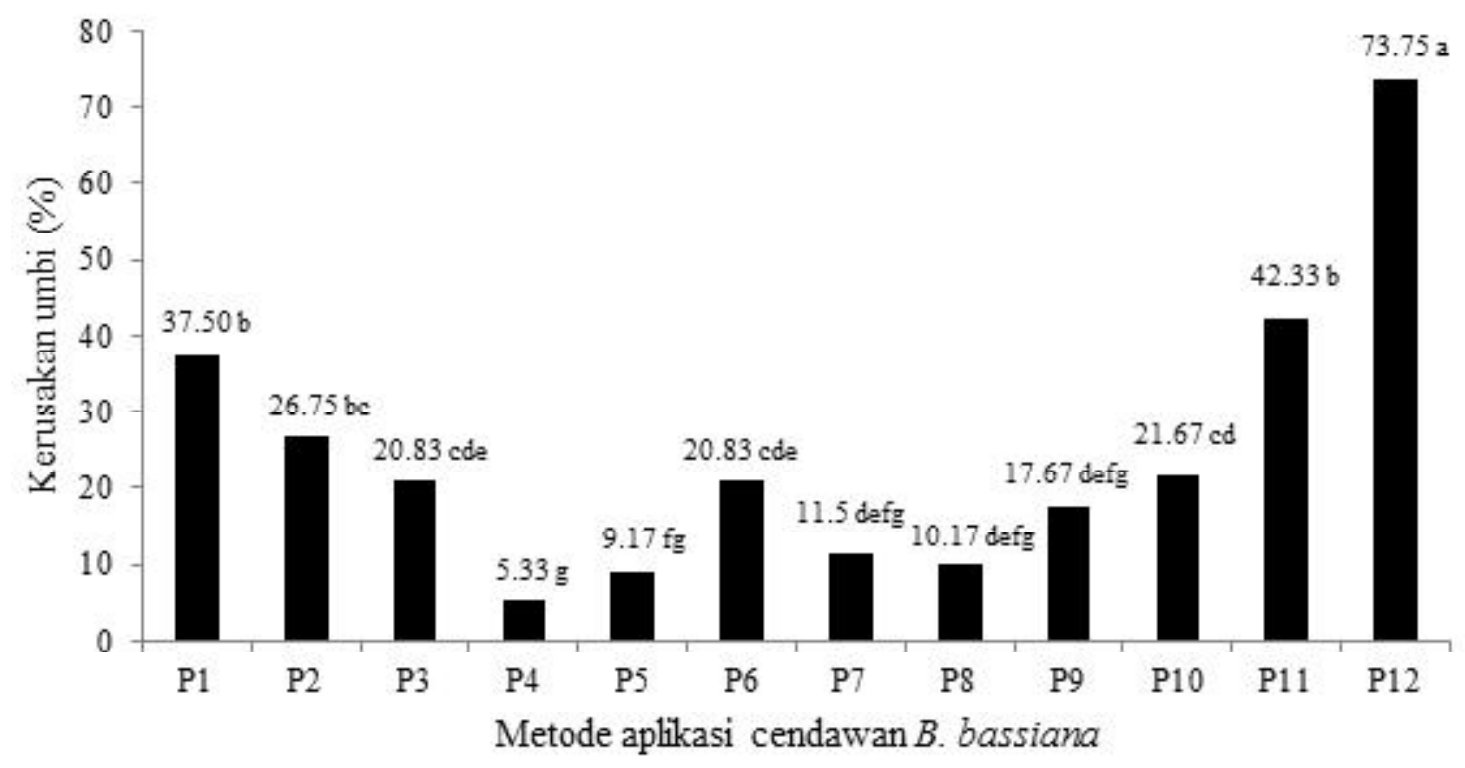

Gambar 2. Efikasi berbagai cara dan frekuensi aplikasi suspensi konidia cendawan B. bassiana untuk membunuh C. formicarius dan dampaknya terhadap kerusakan umbi. $\mathrm{P} 1=$ aplikasi $B$. bassiana di lubang tanam; $\mathrm{P} 2=$ stek direndam 30 menit sebelum tanam; $\mathrm{P} 3=\mathrm{P} 1+\mathrm{P} 2 ; \mathrm{P} 4=\mathrm{P} 1+\mathrm{P} 2+$ aplikasi umur 2, 4, 6, 8, 10 , 12 MST; P5 = P2 + aplikasi umur 2, 4, 6, 8, 10, 12 MST; P6 = P1 + P2 + aplikasi umur 4, 6, 8, 10, 12 MST; P7 = P1 + P2 + aplikasi umur 4, 8, 12 MST; P8 = P1 + P2 + aplikasi umur 4, 8 MST; P9 = P1 + $\mathrm{P} 2+$ aplikasi umur 4 MST; P10 $=\mathrm{P} 1+\mathrm{P} 2+$ aplikasi umur 8 MST; P11 + aplikasi insektisida kimia umur 2, 4, 6, 8, 10, 12 MST; dan P12 kontrol (tanpa pengendalian). 
entomopatogen $B$. bassiana lebih prospektif dalam melindungi kerusakan umbi jika dibandigkan dengan insektisida kimia.

Persentase Kerusakan Umbi. Hasil penelitian menunjukkan bahwa persentase kerusakan umbi terendah sebesar 5\% terjadi pada perlakuan P4 (Gambar 2). Kerusakan umbi terbesar terjadi pada perlakuan tanpa pengendalian (P12), yaitu mencapai $73,75 \%$. Pengendalian penggerek umbi menggunakan cara pencelupan stek ke dalam suspensi konidia $B$. bassiana selama 30 menit dilanjutkan aplikasi dengan cara semprot ke pangkal batang pada umur 2-12 MST (P5) cukup efektif dengan persentase kerusakan umbi akibat gerekan C. formicarius hanya sebesar 9,17\% (Gambar 2) dan tidak berbeda nyata dengan perlakuan P4. Perlakuan P5 suspensi konidia jamur B. bassiana yang menempel pada stek ubi jalar mampu mengolonisasi daerah sekitar batang sehingga umbi yang terbentuk dapat terlindungi dari serangan $C$. formicarius. Ditambah aplikasi suspensi konidia dengan cara semprot pada umur 2-12 HST pada P5 maka dapat menekan imago yang meletakkan telur di sekitar pangkal batang.

Kerusakan umbi akibat gerekan $C$. formicarius yang ditemukan pada perlakuan aplikasi insektisida kimia (P11) tidak berbeda nyata dengan perlakuan P1, yaitu masing-masing 42,33\% dan 37,50\% (Gambar 2). Aplikasi insektisida kimia pada tanaman ubi jalar dengan cara disemprotkan ke pangkal batang tanaman tidak mampu menjangkau imago $C$. formicarius yang menghuni di dalam bongkahan tanah. Hal ini disebabkan imago $C$. formicarius memiliki perilaku yang sangat agresif sehingga serangga bergerak cepat dan bersembunyi ke tempat-tempat yang dianggap aman dari paparan residu insektisida kimia. Imago C. formicarius pada umumnya menghuni daerah perakaran tanaman dengan memanfaatkan rongga-rongga di sekitar perakaran tanaman.

Aplikasi insektisida kimia pada pangkal batang tanaman mengakibatkan imago C. formicarius yang ada di sekitar daerah tersebut berpindah mencari persembunyian ke dalam rongga tanah menuju umbi. Diketahui bahwa kulit umbi dekat pangkal batang merupakan tempat yang disukai oleh imago betina $C$. formicarius untuk meletakkan telurnya (Sakuratani et al. 1994; Samantaray \& Korada, 2016). Larva instar I yang baru keluar dari telur langsung makan umbi yang ada, yang menimbulkan kerusakan pada umbi tersebut.

Perlakuan perendaman pangkal stek bibit ubi jalar yang akan ditanam selama 30 menit (P2) belum mampu menekan kerusakan umbi dari serangan $C$. formicarius. Kondisi ini ditunjukkan dengan persentase serangan umbi oleh penggerek masih cukup tinggi (di atas 26\% (Gambar 2). Dengan demikian, perlakuan P2 ini kurang efektif jika tidak ditindaklanjuti dengan aplikasi penyemprotan $B$. bassiana secara simultan. Ditinjau dari kerusakan umbi (Gambar 3), perlakuan P4 lebih efektif dibandingkan dengan perlakuan-perlakuan lainnya.

\section{Populasi Telur, Larva dan Imago C. formicarius pada} Tiap Umbi. Populasi telur, larva maupun imago $C$. formicarius yang hidup dan digunakan sebagai tolok ukur untuk mengukur efikasi pengendalian menggunakan jamur $B$. bassiana dapat diketahui dengan cara membelah umbi yang sudah dipanen. Hasil pengamatan diperoleh berbagai fase $C$. formicarius, yaitu telur dan larva ditemukan di dalam umbi, sedangkan pada permukaan kulit terluar umbi ditemukan telur dan imago. Jumlah rata-rata telur yang ditemukan di lapisan kulit
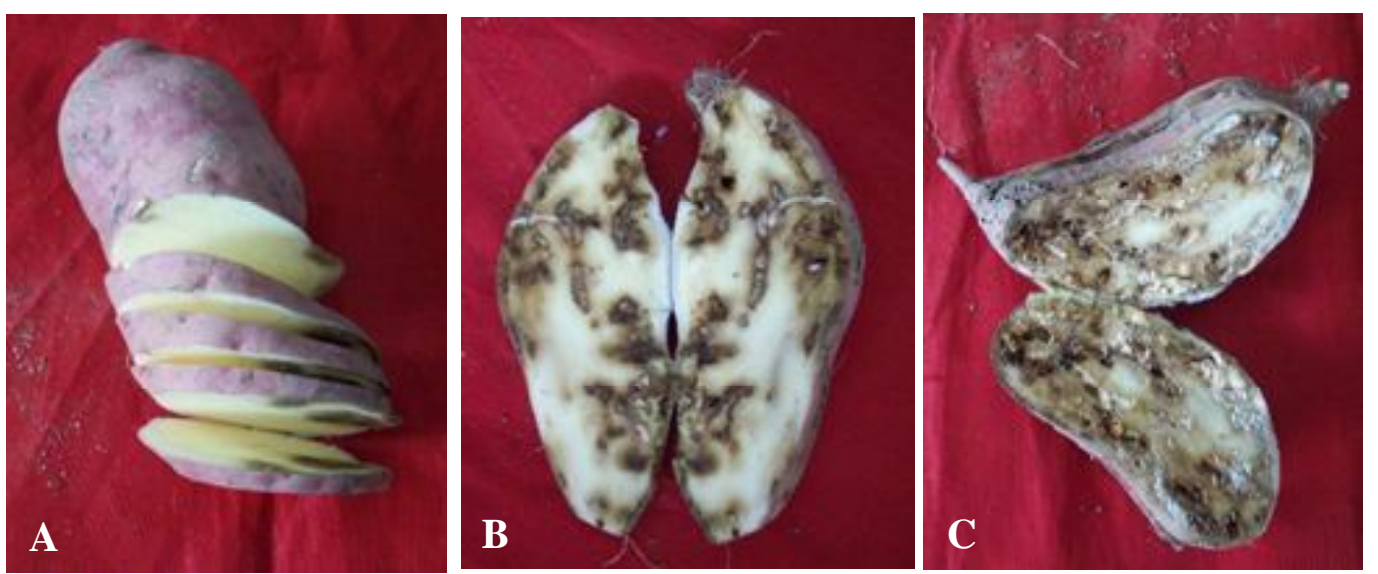

Gambar 3. Keragaan ubi jalar pada; (A) perlakuan P4, (B) umbi yang tergerek larva C. formicarius pada perlakuan insektisida kimia $\mathrm{P} 11$, dan (C) kerusakan umbi oleh larva $C$. formicarius tanpa pengendalian. 
umbi berkisar antara 1-5 butir tiap umbi (Tabel 2). Jumlah telur terbanyak mencapai 5 butir umbi $^{-1}$ pada perlakuan tanpa pengendalian. Jumlah telur terendah yaitu hanya 1 butir umbi ${ }^{-1}$ (pada perlakuan P1). Namun, jumlah larva maupun imago pada perlakuan P1 cukup tinggi, yaitu masing-masing 18 ekor larva umbi ${ }^{-1}$ dan 4 ekor imago umbi $^{-1}$. Kondisi ini disebabkan konidia yang diaplikasikan kemungkinan hilang terhempas air pada waktu penyiraman setiap hari yang dilakukan untuk mempertahankan kelembapan tanah (di polybag).

Rerata jumlah telur pada perlakuan P4 yang ditemukan sedikit, yaitu hanya 1 butir tiap umbi dan tidak berbeda nyata dengan perlakuan P1 (Tabel 2). Jumlah telur $C$. formicarius yang dapat terhitung pada semua perlakuan aplikasi jamur B. bassiana (P1-P10), lebih sedikit kecuali pada perlakuan P5 (5 butir umbi ${ }^{-1}$ ) tidak berbeda dengan aplikasi insektisida kimia ( 5 butir umbi $^{-1}$ ).

Jumlah larva $C$. formicarius pada tiap umbi beragam antar perlakuan, populasi terendah hanya 2 ekor tiap umbi (P4) dan tidak berbeda nyata dengan jumlah larva pada perlakuan P7 maupun P10, yaitu berturutturut 5 dan 6 ekor (Tabel 2). Meskipun tergerek hanya oleh satu ekor larva $C$. formicarius kondisi umbi rusak dan tidak layak dikonsumsi. Jumlah larva $C$. formicarius instar III pada perlakuan insektisida kimia 7 ekor umbi${ }^{1}$ dalam kondisi hidup. Rendahnya jumlah larva $C$. formicarius yang hidup ditemukan pada perlakuan aplikasi insektisida kimia ini terjadi karena larva pada instar I yang baru terbentuk dari telur dan belum berhasil menggerek umbi akhirnya banyak yang mati karena teracuni oleh insektisida kimia yang diaplikasikan ikut terbawa air pada waktu penyiraman.

Jumlah larva yang hidup pada perlakuan P1, P2, P3, P5, P6, P8, dan P9 yang hidup masih relatif banyak yang dapat ditemukan masing-masing 18 (P1 \& P2), 8 (P3), 10 (P5, P6, P8), dan 15 ekor (P9). Keadaan ini disebabkan konidia yang diaplikasikan pada larva yang baru terbentuk akan terhempas air yang disiramkan tiap hari, sehingga konidia tidak berhasil menempel pada tubuh larva. Pada kondisi seperti itu, peluang konidia jamur B. bassiana yang diaplikasikan dapat melakukan penetrasi ke lapisan integumen serangga juga sangat terbatas. Dengan demikian serangga tetap bertahan hidup, karena tubuhnya belum terinfeksi konidia $B$. bassiana. Selanjutnya larva dapat berkembang secara normal di dalam umbi sehingga jumlah larva yang ditemukan pada perlakuan tersebut relatif lebih banyak. Oleh karena itu, untuk meningkatkan efikasi pengendalian menggunakan jamur $B$. bassiana diperlukan penambahan bahan perekat (Jin et al., 2008; Mishra et al., 2013; Mwanburi et al., 2015) atau dapat dikombinasikan dengan formulasi minyak (Ummidi \& Vadlamani 2014) atau ekstrak minyak nabati (Rogerio et al., 2005; Silva et al., 2006; Mohan et al., 2007).

Perlakuan P4 tampak lebih efektif dalam menekan perkembangan populasi $C$. formicarius karena imago yang hidup tidak ditemukan pada perlakuan tersebut

Tabel 2. Efikasi berbagai metode aplikasi suspensi konidia cendawan B. bassiana terhadap populasi telur, larva dan imago C. formicarius

\begin{tabular}{|c|c|c|c|c|}
\hline \multirow[t]{2}{*}{ Kode } & \multirow[t]{2}{*}{ Metode aplikasi suspensi konidia $B$. bassiana } & \multicolumn{3}{|c|}{$\begin{array}{l}\text { Populasi C. formicarius } \\
\text { (ekor per umbi) }^{*}\end{array}$} \\
\hline & & Telur & Larva & Imago \\
\hline P1 & Aplikasi di lubang tanam & $1,0 \mathrm{e}$ & $18,0 \mathrm{bc}$ & $4,0 \mathrm{ab}$ \\
\hline $\mathrm{P} 2$ & Stek direndam selama 30 menit sebelum tanam & $2,0 \mathrm{~cd}$ & $18,0 \mathrm{~b}$ & $1,0 \mathrm{bc}$ \\
\hline $\mathrm{P} 3$ & $\mathrm{P} 1+\mathrm{P} 2$ & $2,0 \mathrm{~cd}$ & 8,0 bcdef & $2,0 \mathrm{bc}$ \\
\hline P4 & $\mathrm{P} 1+\mathrm{P} 2+$ aplk. umur 2, 4, 6,8, 10 dan $12 \mathrm{MST}$ & $1,0 \mathrm{e}$ & $2,0 \mathrm{f}$ & $0,0 \mathrm{c}$ \\
\hline P5 & $\mathrm{P} 2+$ aplk. umur 2, 4, 6, 8, 10 dan $12 \mathrm{MST}$ & $5,0 \mathrm{ab}$ & 10,0 cdef & $0,0 \mathrm{c}$ \\
\hline P6 & $\mathrm{P} 1+\mathrm{P} 2+$ aplk. umur 4, 6, 8, 10 dan $12 \mathrm{MST}$ & $2,0 \mathrm{~cd}$ & 10,0 ef & $0,0 \mathrm{c}$ \\
\hline P7 & $\mathrm{P} 1+\mathrm{P} 2+$ aplk. umur 4, 8 dan $12 \mathrm{MST}$ & $2,0 \mathrm{~cd}$ & 5,0 bcdef & $0,0 \mathrm{c}$ \\
\hline P8 & $\mathrm{P} 1+\mathrm{P} 2+$ aplik. umur 4 dan $8 \mathrm{MST}$ & $3,0 \mathrm{bc}$ & $10,0 \mathrm{bcd}$ & $0,0 \mathrm{bc}$ \\
\hline P9 & $\mathrm{P} 1+\mathrm{P} 2+$ aplik. umur $4 \mathrm{MST}$ & $3,0 \mathrm{bc}$ & 15,0 ef & $1,0 \mathrm{bc}$ \\
\hline P10 & $\mathrm{P} 1+\mathrm{P} 2+$ aplik. umur $8 \mathrm{MST}$ & $2,0 \mathrm{~cd}$ & 6,0 ef & $3,0 \mathrm{abc}$ \\
\hline P11 & Insektisida kimia (stek, 2, 4, 6, 8, 10, 12 MST) & $5,0 \mathrm{ab}$ & 7,0 def & $2,0 \mathrm{bc}$ \\
\hline $\mathrm{P} 12$ & Tanpa pengendalian (Kontrol) & $5,0 \mathrm{a}$ & $40,0 \mathrm{a}$ & $7,0 \mathrm{a}$ \\
\hline
\end{tabular}

MST = minggu setelah tanam, ${ }^{*}$ Angka yang diikuti huruf yang sama dalam satu kolom, tidak berbeda nyata pada uji DMRT taraf 5\%. 
(Tabel 2). Efikasi B. bassiana dalam membunuh imago C. formicarius juga terjadi pada perlakuan P6 dan P7. Keadaan ini disebabkan aplikasi jamur B. bassiana dengan frekuensi lebih banyak mempunyai peluang yang lebih besar bagi konidia untuk dapat berkontak dengan imago sehingga jumlah imago yang terinfeksi oleh jamur juga lebih banyak. Akhirnya jumlah imago yang mati karena aplikasi perlakuan tersebut juga lebih besar dibandingkan dengan perlakuan yang lain. Aplikasi insektisida kimia juga menunjukkan populasi imago $C$. formicarius lebih rendah dibandingkan perlakuan P1 maupun tanpa pengendalian. Rendahnya populasi imago C. formicarius karena insektisida kimia yang diaplikasikan hanya toksik terhadap imago, bukan terhadap telur maupun larva yang ada di dalam umbi. Rendahnya jumlah imago pada perlakuan aplikasi insektisida kimia belum dapat dikatakan bahwa cara pengendalian tersebut efektif karena pada perlakuan insektisida kimia masih banyak ditemukan fase telur dan larva. Sementara itu, pengendalian hayati menggunakan cendawan entomopatogen $B$. bassiana mampu membunuh hampir semua populasi telur, larva maupun imago. Oleh karena itu, efikasi pengendalian harus ditinjau dari jumlah larva yang hidup maupun jumlah telur yang dapat ditemukan pada umbi. Hal ini terjadi karena telur yang masih hidup berpeluang besar berkembang menjadi larva, dan seluruh fase larva yang berada di dalam umbi yang aktif merusak umbi sehingga menyebabkan kerugian besar.

Pengaruh Populasi Larva $C$. formicarius dengan Tingkat Kerusakan Umbi. Populasi serangga khususnya larva berpengaruh langsung terhadap tingkat kerusakan umbi . Kondisi tersebut terjadi karena kerusakan umbi disebabkan oleh fase larva $C$. formicarius yang berlangsung sekitar 18 hari mulai dari larva instar I-V. Hubungan populasi larva $C$. formicarius dengan kerusakan umbi bersifat linier, semakin banyak jumlah larva $C$. formicarius yang ditemukan pada umbi menyebabkan semakin besar tingkat kerusakan umbi yang terjadi (Gambar 4). Persamaan regresi menunjukkan bahwa setiap ekor larva $C$. formicarius dapat menyebabkan kerusakan umbi ubi jalar sebesar 4,4\%. Meskipun kerusakan umbi hanya $4 \%$ perlu mendapat perhatian, hal ini disebabkan bekas gerekan larva pada umbi sudah tidak layak untuk dikonsumsi oleh manusia karena mengandung toksin yang dapat meracuni.

Aplikasi jamur B. bassiana hanya sekali pada lubang tanam maupun perendaman stek bibit ubi jalar sebelum ditanam kurang efektif dalam menekan populasi larva $C$. formicarius karena masih ditemukan larva hingga mencapai 18 ekor tiap umbi (Gambar 5). Pengaruh populasi larva dengan tingkat kerusakan umbi

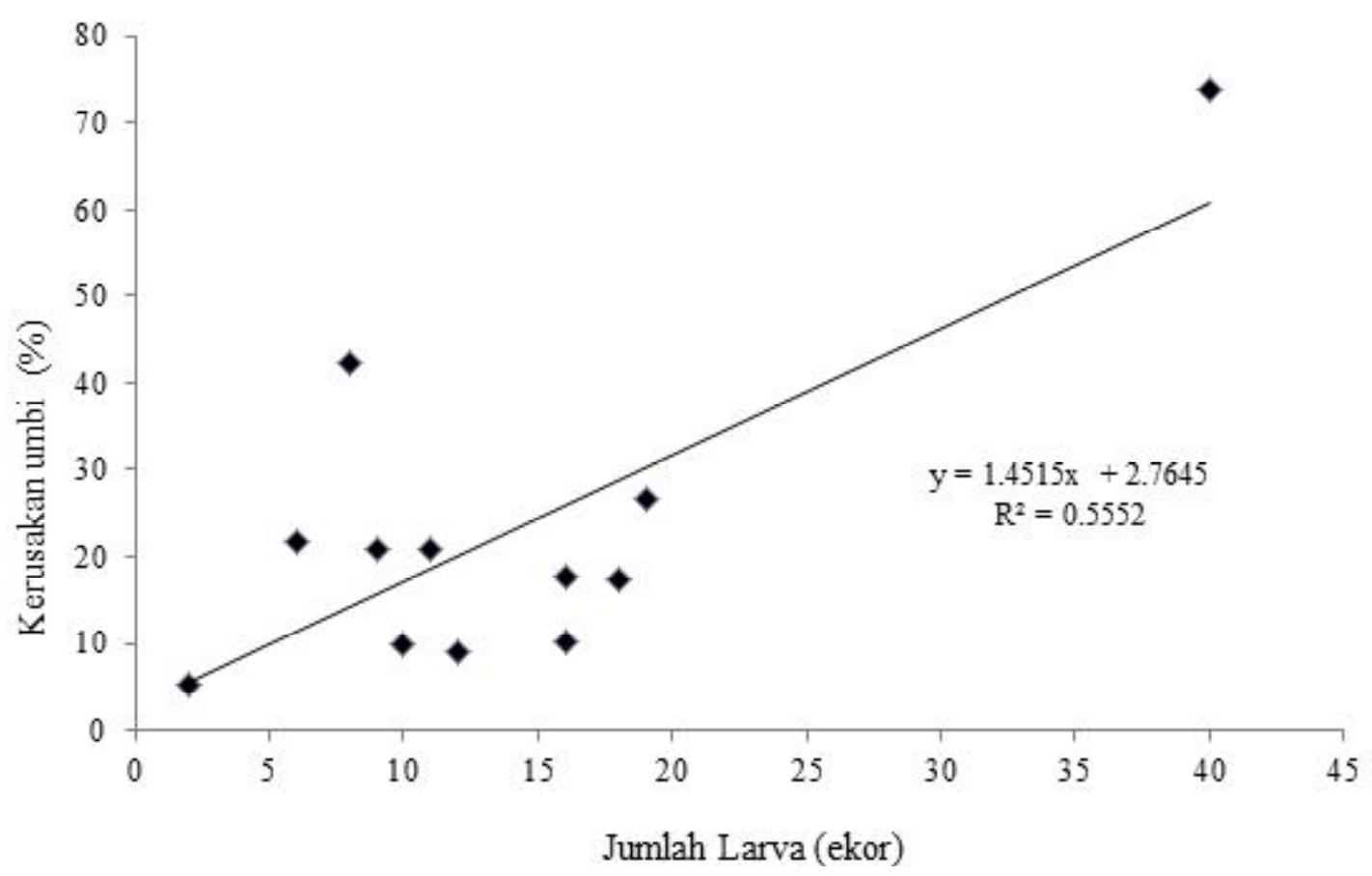

Gambar 4. Hubungan populası larva C. formıcarıus terhadap tıngkat kerusakan umb1 ub1 jalar 


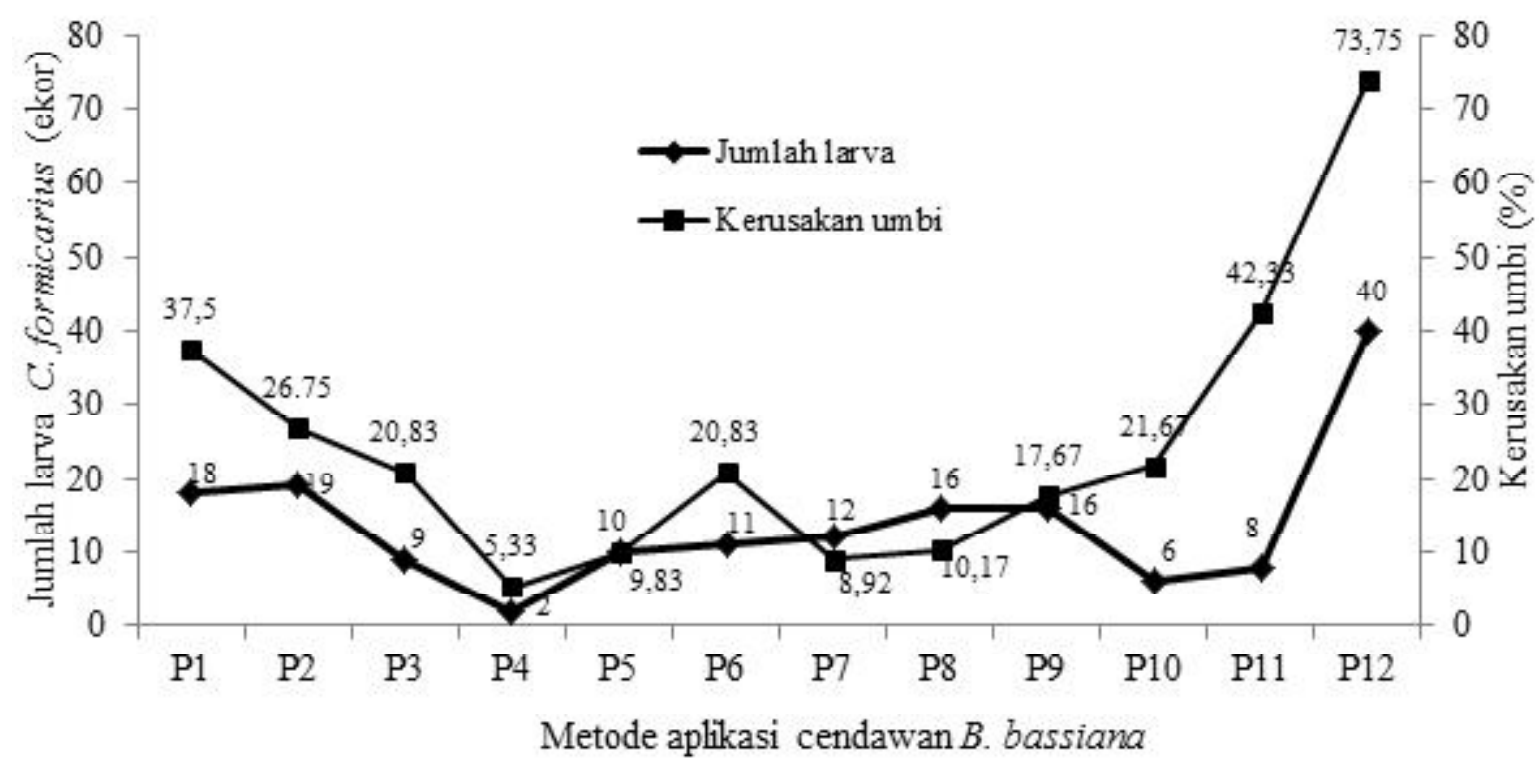

Gambar 5. Pengaruh jumlah larva terhadap kerusakan umbi ubi jalar. $\mathrm{P} 1=$ aplikasi B. bassiana di lubang tanam; $\mathrm{P} 2$ $=$ stek direndam 30 menit sebelum tanam; $\mathrm{P} 3=\mathrm{P} 1+\mathrm{P} 2 ; \mathrm{P} 4=\mathrm{P} 1+\mathrm{P} 2+$ aplikasi umur 2, 4, 6, 8, 10, 12 MST; P5 = P2 + aplikasi umur 2, 4, 6, 8, 10, 12 MST; P6 = P1 + P2 + aplikasi umur 4, 6, 8, 10, 12 MST; $\mathrm{P} 7=\mathrm{P} 1+\mathrm{P} 2+$ aplikasi umur 4, 8, $12 \mathrm{MST} ; \mathrm{P} 8=\mathrm{P} 1+\mathrm{P} 2+$ aplikasi umur 4, $8 \mathrm{MST} ; \mathrm{P} 9=\mathrm{P} 1+\mathrm{P} 2+$ aplikasi umur 4 MST; P10 = P1 + P2 + aplikasi umur 8 MST; P11 + aplikasi insektisida kimia umur 2, 4, 6, 8, 10, 12 MST; dan P12 kontrol (tanpa pengendalian)

tampak jelas pada perlakuan P4 (2 ekor tiap umbi ${ }^{-1}$ dan kerusakan umbi sebesar 5\%). Rendahnya populasi larva pada perlakuan P4 terkait dengan keberadaan atau populasi konidia $B$. bassiana di dalam tanah cukup banyak sehingga mampu mengkolonisasi populasi $C$. formicarius. Ormond et al. (2010) dan Arooni-Hesari et al. (2015) menganjurkan untuk aplikasi konidia $B$. bassiana secara simultan agar diperoleh populasi konidia cukup berlimpah sehingga mampu menginfeksi dan mengkolonisasi hama yang dikendalikan.

Populasi larva yang ditemukan pada perlakuan aplikasi insektisida kimia pada waktu pengamatan sebanyak 7 ekor, tetapi ditinjau dari tingkat kerusakan umbi cukup tinggi yaitu mencapai $42 \%$. Senyawa insektisida kimia mampu membunuh larva dan imago jika aplikasinya tepat sasaran. Namun senyawa tersebut tidak mampu membunuh telur karena senyawa insektisida kimia tidak bersifat ovisidal (membunuh telur). Larva instar I yang baru terbentuk berdasarkan pengamatan juga langsung menggerek umbi. Populasi telur pada perlakuan insektisida kimia tergolong cukup banyak yaitu 4 ekor, kelompok telur tersebut yang berkembang menjadi larva yang menyebabkan kerusakan umbi lebih tinggi. Oleh karena itu, aplikasi insektisida kimia seharusnya tepat waktu dan tepat sasaran karena insektisida kimia tidak mampu bersifat ovisidal seperti jamur entomopatogen B. bassiana.

\section{SIMPULAN}

Pengendalian hama penggerek ubi jalar menggunakan jamur entomopatogen $B$. bassiana lebih efektif dalam menekan populasi serangga dan menekan kerusakan umbi dibandingkan aplikasi insektisida kimia. Aplikasi suspensi konidia jamur B. bassiana satu minggu sebelum tanam, pencelupan stek ke dalam suspensi konidia selama 30 menit, dilanjutkan aplikasi semprot pada umur 2-12 MST efektif untuk mengendalikan $C$. formicarius. Penelitian ini disarankan untuk divalidasi di lapangan pada lahan yang endemik $C$. formicarius untuk memperoleh teknik aplikasi $B$. bassiana yang tepat.

\section{SANWACANA}

Terima kasih kepada saudara Cipto Prahoro, SP selaku Kepala Kebun Percobaan (KP.) Kendalpayak (Malang) dan Heri, SP sebagai koordinator teknis yang telah membantu menyiapkan lahan untuk pelaksanaan penelitian ini serta saudara Antoni yang telah membantu kegiatan di laboratorium maupun di lapangan. Ucapan terima kasih diucapkan kepada Badan Penelitian dan Pengembangan Pertanian (Balitbangtan), Kementerian Pertanian Republik Indonesia yang telah membiayai seluruh penelitian ini. 


\section{DAFTAR PUSTAKA}

Ali A, Sermann H, Lerche S, \& Buttner C. 2009. Soil application of Beauveria bassiana to control Ceratitis capitata in semi field conditions. Commun. Agric. Appl. Biol. Sci. 74: 357-361.

Arooni-Hestari H, Talaei-Hassanloui R, \& Sabahi Q. 2015. Simultaneous use of entomopathogenic fungus Beauveria bassiana and diatomaceous earth against the larvae of Indian meal moth, Plodia interpunctella. Adv. in Biosci. and Biotechnol. 6: 501-507.

Artanti D, Isnawati, Trimulyono G, \& Prayogo Y. 2013. Cendawan entomopatogen Beauveria bassiana dalam mengendalikan telur hama penggerek ubi jalar (Cylas formicarius). LenteraBio 2(1): 4348.

Bugeme DM, Knapp M, Boga HI, Wanjoya AK, \& Maniania NK. 2009. Influence of temperature on virulence of fungal isolates of Metarhizium anisopliae and Beauveria bassiana to the twospotted spider mite Tetranychus urticae. Mycopathol. 67(4): 221-227.

Djufry F, Lestari MS, Afifudin, \& Soplanit A. 2011. Pertumbuhan dan produksi ubijalar di dataran rendah pada berbagai varietas dan sumber stek. J Agrivigor 10(3): 228-234.

Foglie KO. 2007. Priorities for sweet potato research in developing countries results of a survey. HortSci. 42: 1200-1206.

Gindin G, Levski S, Glazer I, Soroker V. 2006. Evaluation of the entomopathogenic fungi Metarhizium anisopliae and Beauveria bassiana against the red palm weevil Rhynchophorus ferrugineus. Phytopar. 34: 370-379.

Haas-Costa J, Alves LFA, \& Daros AA. 2010. Safety of Beauveria bassiana (Bals.) Vuill. to Gallus domesticus L. Braz. Arch. Biol. Technol. 53(2): 465-471.

Hoffmann EJ, Middleton SM, \& Wise JG. 2008. Ovicidal activity of organophosphate, oxadiazine, neonicotinoid and insect growth regulator chemistries on Northern strain plum curcullo Canotrachelus nenuphar. J. of Insect Sci. 8(9): 1-6.
Hue SM \& Low MY. 2015. An insight into sweet potato weevils management: A Review. Psycho: A J. of Entomol. 15: 101-112.

Jackai LE, Sosinski B, \& Jackson DM. 2006. "Occurrence and intra-specific variation of sweet potato weevil (Brentidae: Coleoptera) in relation to its potential spread in southern United States of America and the Caribbean," in ISHS Acta Horticulturae 703: II International Symposium on Sweetpotato and Cassava: Innovative Technologies for Commercialization, pp. 197-204, International Society for Horticultural Science, Leuven, Belgium, 2006.

Jin X, Streett DA, Dunlap CA, \& Lyn ME. 2008. Application of hydrophilic-lipophilic balance (HLB) number to optimize a compatible non-ionic surfactant for dried aerial conidia of Beauveria bassiana. Biol. Cont. 46: 226-233.

Jusuf M. 2007. Memperbaiki efisiensi produksi ubijalar Babi di Kabupaten Jayawijaya Papua. Seminar Nasional dan Ekspose. Percepatan Inovasi Teknologi Pertanian Spesifik Lokasi. Jayawijaya, 5-6 Juni 2007. $25 \mathrm{hlm}$.

Khosravi R, Sendi JJ, Zibaee A, \& Shokrgozar MA. 2015. Virulence of four Beauveria bassiana (Balsamo) (Ascomycete: Hypocreales) isolates on rose sawfly, Arge rosae under laboratory condition. J. of King Saud University Sci. 27(1): 49-53.

Korada RR, Naskar SK, Palaniswami MS, \& Ray RC. 2010. Management of sweet potato weevil Cylas formicarius (Fab.): An Overview. J. of Root Crops 36(1): 14-26.

Kuriwada T, Kumano N, Shiromoto K, \& Haraguchi D. 2009. Copulation reduces the duration of deathfeigning behaviour in the sweet potato weevil Cylas formicarius. Animal Behaviour 78(5): 1145-1151.

Leng H \& Reddy GVP. 2012. Bioactive of selected eco-friendly pesticides against $C y$ las formicarius (Coleoptera: Brentidae). Florida Entomol. 95(4): 1040-1047.

Li H, Huang D, \& Wang Z. 2011. Potential of Beauveria bassiana for biological control of Apriana gumari. Front. of Agric. in China 5(4):666-676. 
Mau YS, Ndiwa ASS, \& Arsa IGBA. 2011. Tingkat ketahanan klon potensial ubi jalar lokal asal NTT terhadap hama lanas (Cylas formicarius). Jurnal Hama Penyakit Tropika 11(2): 139-146.

Meikle WG, Mercadier G, Holst N, \& Girod V. 2008. Impact of two treatments of a formulation of Beauveria bassiana (Deuteromycotina: Hyphomycetes) conidia on Varroa mites (Acari: Varroidae) and on honeybee (Hymenoptera: Apididae) colony health. Exp. Appl. Acarol. 46: 105-117.

Meyling NV \& Eilenberg J. 2007. Ecology of the entomopathogenic fungi Beauveria bassiana and Metarhizium anisopliae in temperate agroecosystems: Potential for conservation biological control. Biol. Cont. 43:145-155.

Mishra S \& Malik A. 2012. Comparative evaluation of five Beauveria isolates for housefly (Musca domestica L.) control and growth optimization of selected strain. Parasitol. Res. 111: 1937-1945.

Mishra S, Kumar P, \& Malik A. 2013. Evaluation of Beauveria bassiana spore compatibility with surfactants. Inter. J. of Medical, Biomedical, Bioengin. and Pharma. Engin. 7(1): 8-13.

Mohan MC, Reddy NP, Devi UK, Kongara K, \& Sharma HC. 2007. Growth and insect assays of Beauveria bassiana with neem to test their compatibility and sinergism. Biocont. Sci. and Technol. 17(10): 1059-1069.

Mwanburi LA, Laing MD, \& Miller RM. 2010. Laboratory screening of insecticidal of Beauveria bassiana and Paecilomyces lilacinus against larval and adult housfly (Musca domestica L.). African Entomol. 18(1): 38-46.

Mwanburi LA, Laing MD, \& Miller RM. 2015. Effect of surfactants and temperature on germination and vegetative growth of Beauveria bassiana. Braz J. Microbiol 46(1): 67-74.

Ondiaka S, Maniania NK, Nyamasyo GHN, \& Nderitu JH. 2008. Virulence of the entomopathogenic fungi Beauveria bassiana and Metarhizium anisopliae to sweetpotato weevil Cylas puncticollis and effects on fecundity and egg viability. Ann. Appl. Biol.153: 41-48.
Ormond EL, Thomas APM, Pugh PJA, Pell JK, \& Roy HE. 2010. A fungal pathogen in time and space: the population dynamics of Beauveria bassiana in lonifer forrest. FEMS Microbiol. Ecol. 74:146-154.

Prayogo Y. 2012. Virulensi beberapa isolat cendawan entomopatogen Beauveria bassiana (Balsamo) Vuill. untuk mengendalikan penggerek ubi jalar Cylas formicarius. Prosiding Seminar Nasional Hasil Penelitian Tanaman Aneka Kacang dan Umbi Tahun 2011. Pusat Penelitian dan Pengembangan Tanaman Pangan, Badan Penelitian dan Pengembangan Pertanian. hlm:738-754.

Prayogo Y. 2013. Toksisitas cendawan Beauveria bassiana Vuill. (Balsamo) terhadap telur dan larva penggerek ubi jalar Cylas formicarius (Coleoptera: Curculionidae). Prosiding Seminar Nasional Hasil Penelitian Tanaman Aneka Kacang dan Umbi Tahun 2013. Pusat Penelitian dan Pengembangan Tanaman Pangan, Badan Penelitian dan Pengembangan Pertanian. hlm:669-681.

Qazzaz FO, Al-Masri MI, \& Barakaf RM. 2015. Effectiveness of Beauveria bassiana native isolates in the biological control of the Mediterranean fruit fly (Ceratitis capitata). $A d v$. in Entomol. 3: 44-55.

Reddy GVP, Gadi N, \& Talanao AJ. 2012a. Ef- ficient sex pheromone trapping: catching the sweetpotato weevil Cylas formicarius. J. Chem. Ecol. 38: 846-853.

Reddy GVP, McConnel J, \& Badilles AE. 2012b. Estimation of the population density of the sweetpotato weevils on the Mariana Islands. $J$. Entomol. Acarol. Res. 44: 20-23.

Reddy GVP, Zhoo Z, \& Humber RA. 2014. Laboratory and field efficacy of entomopathogenic fungi for the management of the sweet potato weevil, Cylas formicarius (Coleoptera: Brentidae). J. of Invertebr. Pathol. 122: 10-15.

Reddy GVP \& Chi H. 2015. Demographic comparison of sweet potato weevil reared on a major host Ipomoea batatas and an alternative host $I$. triloba. Sci. Res. 5: 1-9. 
Riyanti N, Isnawati, Trimulyono G, \& Prayogo Y. 2013. Pengaruh cara aplikasi dan frekuensi pemberian cendawan entomopatogen Beauveria bassiana untuk mengendalikan hama boleng (Cylas formicarius) dan tingkat kerusakan yang ditimbulkannya pada ubi jalar. LenteraBio 2(1): 49-56.

Rogerio AD, Martinez SS, \& Menezes. AOJr. 2005. Compatibility of the fungus Beauveria bassiana (Bals.) Vuill (Deuteromycetes) with extracts of neem seeds and leaves and the emulsible oil. Neotrop Entomol 34: 601-606.

Sakuratani Y, Sugimoto T, Setokuchi O, Kamikado T, Kiritani K, Okada T. 1994. Diurnal changes in microhabitat usage and behavior of Cylas formicarius (Fabricius) (Coleoptera: Curculionidae) Adults. Appl. Entomol. Zool. 29(3): 307-315.

Saleh N \& Rahayuningsih StA. 2013. Pengendalian terpadu penyakit kudis (Sphaceloma batatas Saw.) pada ubijalar. Buletin Palawija 25: 37-44.

Samantaray T, Korada RR. 2016. Electrophysiological and behavioural respons of sweet potato weevil Cylas formicarius to green leaf volatiles and terpenoids. Res. Comm. Curr. Sci. 110(5): 902908.

Shams G, Safaralizadeh MH, Imani S, Shoja M, \& Aramidah S. 2011. A laboratory assessment of the potential of the entomopathogenic fungi Beauveria bassiana (Beauvarin C) to control Callosobruchus maculatus (F.) (Coleoptera: Brucidae) and Sitophilus granaries (L.) (Coleoptera: Curculionidae). Afr. J. Microbiol. Res. (10): 1192-1196.

Sharififar M, Mossadegh MS, Vazirianza B, \& Mahmoudaba AZ. 2011. Laboratory evaluation of pathogenicity of entomopathogenic fungi Beauveria bassiana (Bals.) Vuill. and Metarhizium anisopliae (Metch.) Sorok. to larvae and adults of the housefly Musca domestica L. (Diptera: Musxidae). Asian J. of Biol. Sci. 4: 128-137.

Shi WB, Feng MG, \& Liu SS. 2008. Sprays of emulsifiable Beauveria bassiana formulation are ovicidal towards Tetranychus urticae (Acari: Tetranychidae) at various regimes of temperature and humidity. Exp.Appl. Acarol. 46: 247-257.
Silva RZD, Neves PMOJ, Santoro PH, \& Cavaguchi ESA. 2006. Effect of agrochemicals based on vegetable and mineral oil on the viability of entomopathogenic fungi Beauveria bassiana (Bals.) Vuillemin, Metarhizium anisopliae (Metsch.) Sorokin and Paecilomyces sp. Bainer. Bioassay. 1: 667-674.

Smith TP \& Hammond AM. 2006. Comparative susceptibility of sweetpotato weevil (Coleoptera: Brentidae) to selected insecticides. J. Econ. Entomol. 99: 2024-2029.

Stafford KC \& Allan SA. 2010. Field applications of entomopathogenic fungi Beauveria bassiana and Metarhizium anisopliae F52 (Hypocreales: Clavicipaceae) for the control of Ixodes scapularis (Acari: Ixodidae). J. Med. Entomol. 47: 1107-1115.

Stanghellini ME \& El-Hamalawi ZA. 2005. Efficacy of Beauveria bassiana on colonized millet seed as a biopesticide for the control of short flies. Hort. Sci. 40: 1384-1388.

Suman DS, Parashar BD, \& Prakash S. 2010. Efficacy of various insect growth regulators on organophosphate resistant immatures of Culex quinquefasciatus (Diptera: Culicidae) from different geographical areas of India. J. Entomol. $7: 33-43$.

Suwarto, Setiawan A, \& Septariasari D. 2006. Pertumbuhan dan hasil dua klon ubijalar dalam tumpangsari dengan jagung. Bul. Agron. 34(2): 87-92.

Tarafdar J \& Sarkar MA. 2006. Managing sweet potato weevil Cylas formicarius in West Bengal, India by some chemicals, bioproducs and sex phereomone traps. Acta. Hort. 703: 189-196.

Ummidi VRS \& Vadlamani P. 2014. Preparation and use of oil formulations of Beauveria bassiana and Metarhizium anisopliae against Spodoptera litura larvae. African J. of Microbiol. Res. 8(15): 1638-1649.

Zimmermann G. 2007. Review of the entomopathogenic fungi Beauveria bassiana and $B$. brongniartii. Biocont. Sci. Technol. 17: 553-596. 